\title{
Contribution of Agro-Hydrological Modeling in the Evaluation of Water Availability of an Ungauged Basin Reservoir in Côte d'Ivoire: Case of the Loka Reservoir in Bouaké
}

\author{
Kouao Armand Anoh*, Kouakou Séraphin Konan, Sampah Georges Eblin, Ange Victorine Atcho, \\ Kouakou Lazare Kouassi
}

Water and Environment Science and Technology Laboratory, Jean Lorougnon Guedé University, Daloa, Côte d'Ivoire

Email: ^anohkoua@gmail.com

How to cite this paper: Anoh, K.A., Konan, K.S., Eblin, S.G., Atcho, A.V. and Kouassi, K.L. (2021) Contribution of AgroHydrological Modeling in the Evaluation of Water Availability of an Ungauged Basin Reservoir in Côte d'Ivoire: Case of the Loka Reservoir in Bouaké. Computational Water, Energy, and Environmental Engineering, 10, 117-130.

https://doi.org/10.4236/cweee.2021.103009

Received: July 2, 2021

Accepted: July 23, 2021

Published: July 26, 2021

Copyright $\odot 2021$ by author(s) and Scientific Research Publishing Inc. This work is licensed under the Creative Commons Attribution International License (CC BY 4.0).

http://creativecommons.org/licenses/by/4.0/

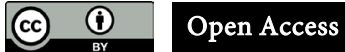

\begin{abstract}
The city of Bouaké, the second biggest city of Côte d'Ivoire, experienced a water shortage in 2018 that lasted four months due to the drying up of the Loka reservoir, which supplies two-thirds of the city. The challenge of the Loka reservoir is that it is located in an ungauged basin where very few hydrological studies have been carried out, despite the recurrent problems of access to drinking water. In the purpose to better understand the phenomena that caused this temporary drying of the dam, the methodology implemented was based on agro-hydrological modeling with SWAT using a regionalization technique of a nearby watershed. The model performance was assessed using three statistical indices (the Nash-Sutcliffe coefficient (NS), the coefficient of determination $\left(\mathrm{R}^{2}\right)$ and the percentage of bias (PBIAS)) and the visual appreciation of hydrographs for monthly series. The statistical indices appear satisfactory with a NS and $\mathrm{R}^{2} \geq 0.6$ both for calibration and validation, and a PBIAS of -11.2 and -3.8 respectively for calibration and validation. The hydrological modeling of Loka basin has shown the impact of climate change already reported by some authors as well as anthropization. Thus, while the reservoir records a decrease in its water volume estimated at $384,604 \mathrm{~m}^{3}$ each year, the water demand undergoes an increase of $122,033 \mathrm{~m}^{3}$ per year.
\end{abstract}

\section{Keywords}

Loka Basin, Hydrological Modeling, SWAT, SUFI-2, Water Availability

\section{Introduction}

In constant interaction with all the elements of the biosphere, water is undoub- 
tedly the non-substitutable substance, essential for life. Its management linked to that of other natural resources has motivated major international bodies to include it among the Millennium Development Goals [1]. In Côte d'Ivoire, the pressure on the availability of drinking water continues to grow due to the demography growth and uncertainties related to climate change [2] [3] [4] [5] [6]. Indeed, an unsuitable and insufficiently planned management has created during the first half of 2018 in various areas of the country, including Ferkessédougou, Niakaramandougou, Tiéningboué and Bouaké, disruptions in the drinking water supply [7]. In Bouaké, Côte d'Ivoire's second largest city, concerns about the management of drinking water are very real. Indeed, the populations of Bouake city have been faced during almost four months in 2018, with an unprecedented water shortage. The Loka dam, which supplies two-thirds of the city with drinking water, has dried up. This drying up of the reservoir observed during the months of May, June and July 2018 has caused much tension. Among the factors indexed of this drying up are the Ivorian government through the Water Distribution Company in Côte d'Ivoire (SODECI), the climate change and the anthropization. In addition to these factors, the socio-political crisis that shook Côte d'Ivoire in 2011 has greatly affected the drinking water supply, due to the displacement of populations to Bouaké and its surroundings [8]. Yet this demographic growth, in addition to increasing the drinking water request [9], has exerted pressure on the natural environment through constant modification of the landscape for agricultural purposes, thus contributing to the emergence of bare soil [10]. Moreover, the increase in bare soil is a source of increased erosion [11]. In addition, it leads to a regular deposition of sediment in the reservoir during runoff on the watershed. These sediments, which for the most part carry pollutants, accumulate in the drinking water reservoir by gradually reducing its water storage capacity. Based on this observation, it seems more than urgent to set up a monitoring and decision support tool to prevent possible disruptions in the drinking water availability. Such management requires a more detailed knowledge of agro-hydrological processes involved in the water balance. Therefore, the main objective of this study is to understand the hydrological functioning of Loka reservoir used to supply Bouaké city drinking water in order to prevent future shortages of drinking water. To achieve this objective, the functionalities of SWAT model combined with Geographic Information Systems are used.

\section{Material and Methods}

\subsection{Presentation of the Study Area}

The Loka basin is located in the administrative region of Gbêkê, precisely the northwest of the Bouaké city. The Loka basin is a subbasin of Kossou Lake (Figure 1). It is geographically located between $07^{\circ} 41$ and $07^{\circ} 48$ North latitudes and between $05^{\circ} 05$ and $05^{\circ} 15$ of West longitudes. The Loka catchment, whose altitude varies between $199 \mathrm{~m}$ and $364 \mathrm{~m}$ drains an area of $133.21 \mathrm{~km}^{2}$. That of Kossou drains an area of $32,671.82 \mathrm{~km}^{2}$. 


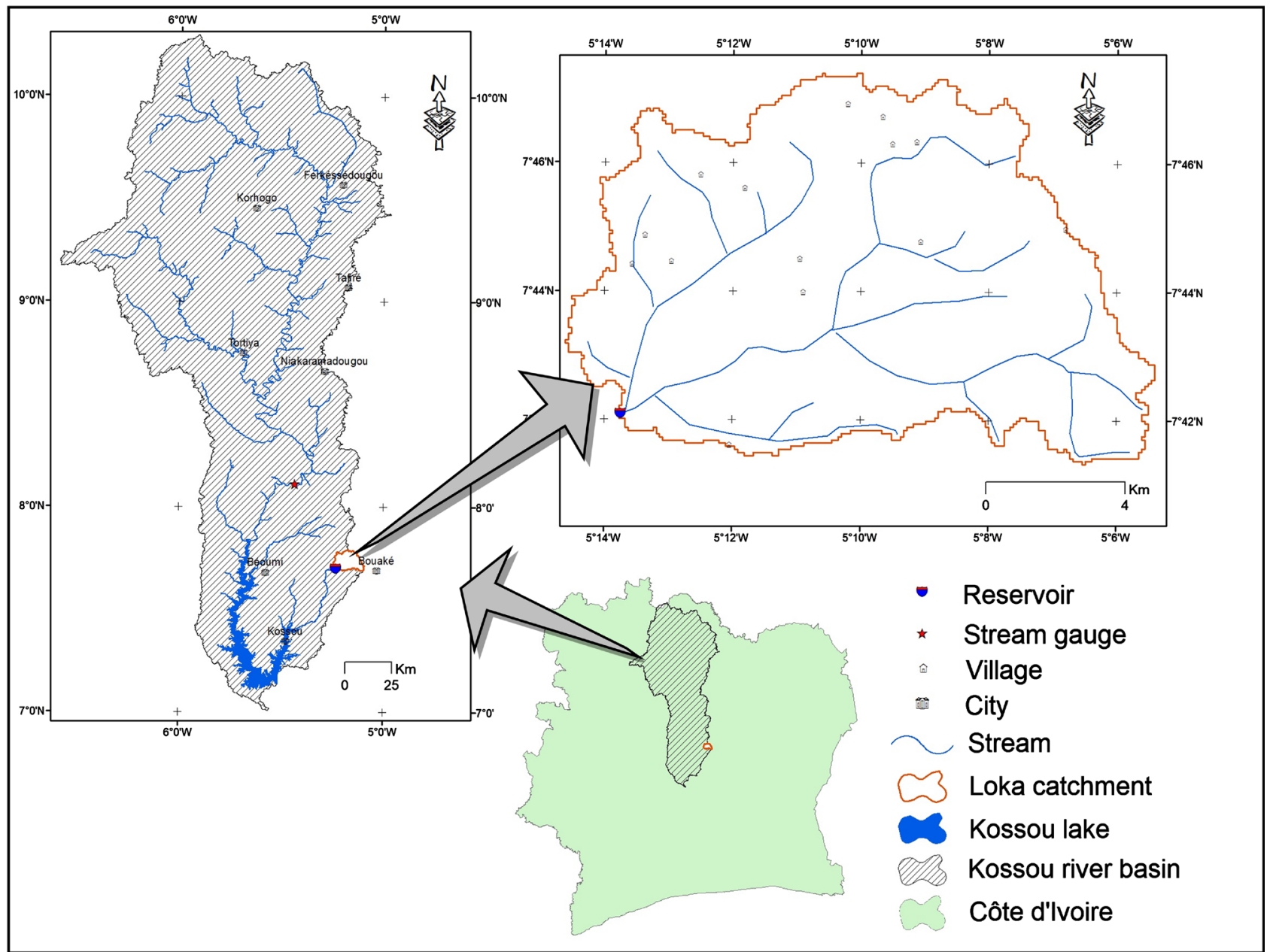

Figure 1. Presentation of Loka basin.

The soil of the Loka watershed is a transition between savannas' ferruginous and forests' ferralitic soils. However, the basin is dominated by a ferruginous soil type with a sandy covering. As for the vegetation, it is composed of grassy savannah and trees. Climatically, the Loka basin is located in the transitional equatorial climate, more known as the Baoulean climate. Unfortunately, according to the conclusions of several authors including Ouedraogo [12], Ardoin [13], Goula et al. [14], Kouassi [15], Kouassi et al. [16], since 1965, rainfall in the basin has been decreasing. Demographically, Bouaké is the second largest city in Côte d'Ivoire. It records an annual growth rate of $0.95 \%$ with a population that has increased from 461,617 inhabitants in 1998 to 536,719 inhabitants in 2014 [8]. Among other factors of this strong demographic growth, the 2011 post-election crisis combined with the good forest cover of Bandama watershed [17] [18] [19] and [20]. With this high population density, the drinking water supply of Bouaké city is provided for $80 \%$ by surface water from three reservoirs (Kan, Gonfreville and Loka). The Loka reservoir provides two-thirds of Bouaké city and some surrounding village drinking water supply. Unfortunately, the latter experienced a drying up in 2018 during the months of May, June and July 
(Figure 2).

\subsection{Description and Implementation of the Model Used}

The model used in this study is called SWAT "Soil and Water Assessment Tool" [21]. SWAT was developed by researchers at the United States Department of Agriculture (USDA) [20]. The choice of this model in this study is largely due to its ability to easily reproduce water cycle in a simplified manner in highly anthropized and ungauged watersheds [22]. It is also freely downloadable from the Internet and its open source code allows improvements through the vast scientific community that supports it. It also has several advantages, notably climate forecasting and impact simulation of planning scenarios. The SWAT agro-hydrological model is therefore a deterministic, physical, conceptual and semi-distributed model that operates on a continuous basis with a daily time step. The SWAT version used in this study is coupled with ArcGIS 10.0 GIS software. [18] in their work have summarized the implementation of SWAT model into 3 major successive phases.

\subsubsection{Preprocessing Phase}

The pre-processing phase consists of an adaptation of the standardized physiographic data for the entire American territory to the realities of Côte d'Ivoire. In others words, it consists in adding or adjusting certain parameters of the model source code (soil (usersoil), climate (userwgn)) [21] and agronomic (sowing and harvesting dates, fertilizer and nutrient inputs, tillage and cultural practices) [23] [5] to the realities of the Loka basin.

\subsubsection{Processing Phase}

Since the Loka basin is ungauged, the modeling of water flow to the Loka reservoir was based on one regionalization technique that is the spatial proximity. Indeed, studies reported in the scientific literature by [24] [25] [26] and [27]

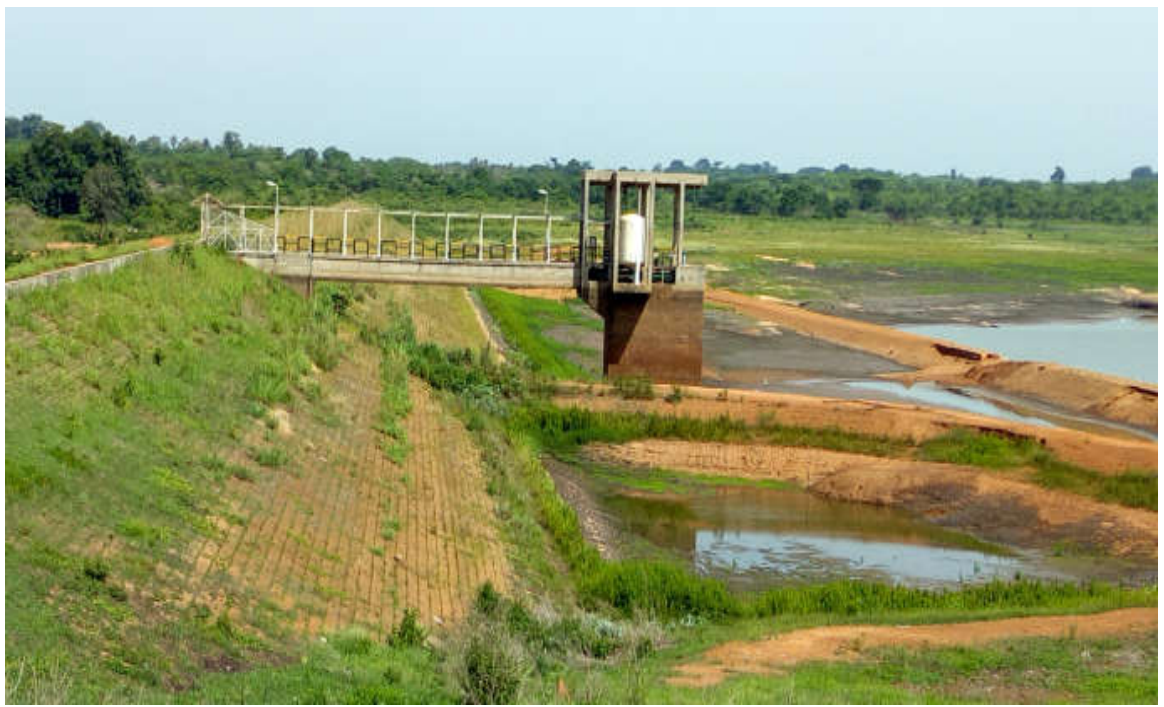

Figure 2. Drainage of Loka reservoir in Bouaké in 2018. 
have shown that among the three different methods of regionalizing hydrological model parameters (spatial proximity, physical similarity and linear regression), the spatial proximity approach leads to better results. The hypothesis that justifies this approach is that a spatially close gauged and ungauged basin should in theory have similar physical characteristics. Similarly, both basins should react in the same way to meteorological events [28]. Therefore, this phase was based on the Kossou Lake watershed in which the Loka River basin is located. The implementation of SWAT on the Kossou lake watershed requires a large number of files which are of two types (raster and point). Thus, the following data were entered in order in the model:

- the Digital Elevation Model (DTM) (established from Shuttle Radar Topography Mission (SRTM) images, with a spatial resolution of one arc per second; i.e. $30 \mathrm{~m}$ acquired via American site: http://earthexplorer.usgs.gov/);

- the location of hydrometric stations (the Marabadiassa hydrometric station located upstream of the Loka basin has monthly flow data for the period from 1981 to 2005, with gaps from 1997 to 2002. The streamflow data were made available by the National Drinking Water Office (ONEP) of the Human Hydraulics Department (DHH);

- the morphometric characteristics and the volumes of water withdrawn monthly from the reservoir from 1987 to 2019;

- the soil map established by FAO in 1995 with a spatial resolution of $10 \mathrm{~km}$;

- the land use map with a spatial resolution of $30 \mathrm{~m}$ was obtained from Landsat 7 ETM+ images of 12/15/2005 via the site https://glovis.usgs.gov/;

- daily weather data from 1980 to 2006 (precipitation, temperatures (minimum and maximum) from the CRU website:

http://www.cru.uea.ac.uk/ timm/data/index-table.

In order to take into account the heterogeneity of the basin, SWAT has divided the basin into several Hydrological Response Units (HRU). Note that a HRU is the result of the intersection of three unique elements (land use, soil and slope) in a subbasin. Also, in order to increase the accuracy of the model, the several HRUs option in each subbasin was chosen. The last adjustments of this phase concerned the calculation of potential evapotranspiration (PET), water flow and runoff. The PET was defined using the Penman-Monteith equation, water flow by the variable storage method and runoff by the Curve Number (CN) method. Neitsch et al. [29] propose a very detailed description (phenomena, processes and equations) of agro-hydrological modeling with SWAT in the user manual.

\subsubsection{Post-Processing}

The last adjustments of this phase concerned the calculation of potential SWAT is a complex model with many parameters that make it difficult to optimize. Indeed, it includes 629 parameters on which it is possible to adjust to have a good performance of model [5] [30]. In addition to these parameters, several uncertainties may arise during the SWAT model implementation. These uncertainties 
contribute to reduce its optimization. Therefore, a sensitivity and uncertainty analysis is required. To identify the parameters and quantify the uncertainties, the SUFI-2 (Sequential Uncertainty Fitting version-2) algorithm of the SWAT-CUP (SWAT-Calibration and Uncertainty Program) software of [31] was used. Note that SWAT-CUP which is increasingly used by the SWAT community is an external software tool allowing SWAT users to realize automatic calibration with more comfort and efficiency [32]. In SWAT-CUP, SUFI-2 uses the Latin-OneAt-a-Time (LH-OAT) Hypercube method [33] as a method for sampling sensitive parameters. The LH-OAT method involves changing one parameter at a time, while the other parameters are left untouched To avoid sampling all 629 parameters, the sensitivity analysis was based on the literature on the use of SWAT model in Côte d'Ivoire by [5] [11] [18] [20] [30] [34] [35] [36]. At the uncertainties level, two variables were used to quantify their inclusion by SUFI-2 algorithm [37] [38]. These are notably the P-factor, which represents the degree to which all uncertainties have been taken into account (namely the percentage of measured data framed by $95 \%$ uncertainty prediction (95PPU)) and the $\mathrm{R}$-factor, which is the thickness of the 95PPU band. The P-factor and the $\mathrm{R}$-factor both vary from 0 to 1 ; with 1 as optimum for P-factor and 0 as optimum for R-factor in regards to water flows [31] [39]. Furthermore, to be able to realistically reproduce the Loka reservoir water flows, SWAT needs observed hydrometric data series. According to the application [40] index calculated on the basis of the Marabadiassa station water flows (situated on the Kossou lake watershed), the years 1983-1985, 1987, 1988 and 1991 correspond to dry years, while the years 1995-1997 and 2002-2004, correspond to wet years. Thus, the observed hydrometric data were dived into a calibration period (1983 to 1991) and a validation period (1995 to 2004). Three years (1980-1982) were used for model warming. Several criteria are used in the literature to gauge the goodness of the stream flow simulations. These criteria can be either visual or quadratic. The visual criterion consists in looking at the similarities between the observed and simulated hydrographs. As for the quadratic criteria, also called "objective function", they are expressed in statistical equations. In this study, three statistical criteria widely used in most studies with SWAT model were used. These are the Nash-Sutcliffe coefficient "NS" (Equation (1)), the coefficient of determina-

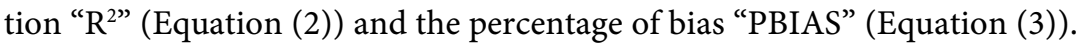

$$
\begin{gathered}
\mathrm{NS}=1-\frac{\sum_{i=1}\left(Q_{m}-Q_{s}\right)^{2}}{\sum_{i=1}\left(Q_{m}-\bar{Q}_{m}\right)^{2}} \\
\mathrm{R}^{2}=\frac{\left[\sum_{i=1}\left(Q_{m}-\bar{Q}_{m}\right)\left(Q_{s}-\bar{Q}_{s}\right)\right]^{2}}{\sum_{i=1}\left(Q_{m}-\bar{Q}_{m}\right)^{2} \sum_{i=1}\left(Q_{s}-\bar{Q}_{s}\right)^{2}} \\
\operatorname{PBIAS}(\%)=100 \times \frac{\sum_{i=1}^{n}\left(Q_{m}-Q_{s}\right)}{\sum_{i=1}^{n} Q_{m}}
\end{gathered}
$$

With $Q_{m}=$ observed flow, $Q_{s}=$ simulated flow, $\bar{Q}_{m}=$ average of measured 
flows and $\bar{Q}_{s}=$ average of simulated flows.

NS varies from $-\infty$ to 1 . NS is considered "good" when it is $\geq 0.5$ and "very good" above 0.75 [41]. $\mathrm{R}^{2}$ varies from 0 to 1 . An $\mathrm{R}^{2}$ value greater than 0.5 would reflect good agreement between observed and simulated data [42]. PBIAIS is between $\pm 25 \%$ [43]. The optimal PBIAS value (zero) indicates a perfect simulation of the model [32]. A positive PBIAS indicates an underestimation of the model while a negative PBIAS demonstrates an overestimation of the model [31] [41].

\section{Results and Discussion}

The implementation of SWAT model made it possible to discretize 251 subbasins for a minimum threshold of $75 \mathrm{~km}^{2}$. The model was simulated for a period of 29 years over the period 1978 to 2005 . The ability of SWAT model to restore water flows from the Loka reservoir is based on the examination of the performance values reflected by the static tests and the similarity of the observed and simulated hydrographs.

\subsection{Sensitivity Analysis}

The sensitivity analysis applied to the 14 hydrological parameters showed 9 parameters sensitive to the simulation of water flows from the Marabadiassa hydrometric station. The global sensitivity of these 9 parameters and their readjusted values are summarized in Table 1.

According to Abbaspour [31] [39], more the higher absolute value of t-stat and P-value close to zero (0), and more the sensitivity of the parameter is important. Thus, the global sensitivity analysis of the SWAT model showed, in decreasing order, that the most sensitive parameters were the groundwater drying coefficient (ALPHA_BF), the effective hydraulic conductivity of the main channels (CH_K2), the initial "SCS" runoff curve number for the moisture condition II (CN2), the maximum canopy storage (CANMX), the available water capacity of the soil layer (SOL_AWC), soil evaporation compensation factor (ESCO),

Table 1. Global sensitivity and adjusted model parameters.

\begin{tabular}{cccccc}
\hline Ranking & Parameter Name & t-Stat & P-Value & Initial value & Final calibrated Value \\
\hline 1 & ALPHA_BF.gw & 8.915 & 0.000 & 0.048 & 0.50 \\
2 & CH_K2.rte & 4.653 & 0.000 & 0.0 & 230.83 \\
3 & CN2.mgt & -2.385 & 0.017 & $74-92$ & $-0.44 \%$ \\
4 & CANMX.hru & 2.168 & 0.031 & 0.0 & 99.33 \\
5 & SOL_AWC.sol & -1.886 & 0.061 & $0.093-0.175$ & $+0.28 \%$ \\
6 & ESCO.hru & 0.951 & 0.342 & 0.0 & 0.31 \\
7 & CH_N2.rte & 0.732 & 0.464 & 0.014 & 0.05 \\
8 & GW_DELAY.gw & 0.697 & 0.486 & 31.0 & 390.25 \\
9 & GWQMN.gw & -0.590 & 0.953 & 0.0 & 4050.57 \\
\hline
\end{tabular}


Manning's roughness coefficient ( $\left.\mathrm{CH} \_\mathrm{N} 2\right)$ of the main channels, the time for groundwater transiting through the surface water table to reach the stream (GW_DELAY), and the threshold depth of water in the shallow aquifer required for return flow to occur (GWQMIN). All of these sensitive parameters have also been identified as sensitive parameters by many authors including [5] [18] [20] [30] [34] [36] [45] [46] [47] [48].

\subsection{Objective Function}

The best performance criteria were obtained after 4 iterations of 500 simulations. The analysis of the statistical indices (Table 2) shows that the stream flow simulation is satisfactory. Indeed, the performance of the model obtained in calibration as well as validation respects the conditions of Van Liew et al. [49] and Moriasi et al. [43]. Moreover, the performance remains very close to the work of Schuol et al. [37] and [30].

Figure 3 graphically illustrates the evolution of statistical criteria at the Marabadiassa station (subbasin 191).

Table 2. Statistical criteria for model performance.

\begin{tabular}{cccccc}
\hline Period & P-factor & R-factor & $\mathbf{R}^{2}$ & NS & PBIAS \\
\hline Calibration & 0.83 & 0.98 & 0.68 & 0.66 & -11.2 \\
Validation & 0.81 & 1.08 & 0.59 & 0.59 & -3.8 \\
\hline
\end{tabular}

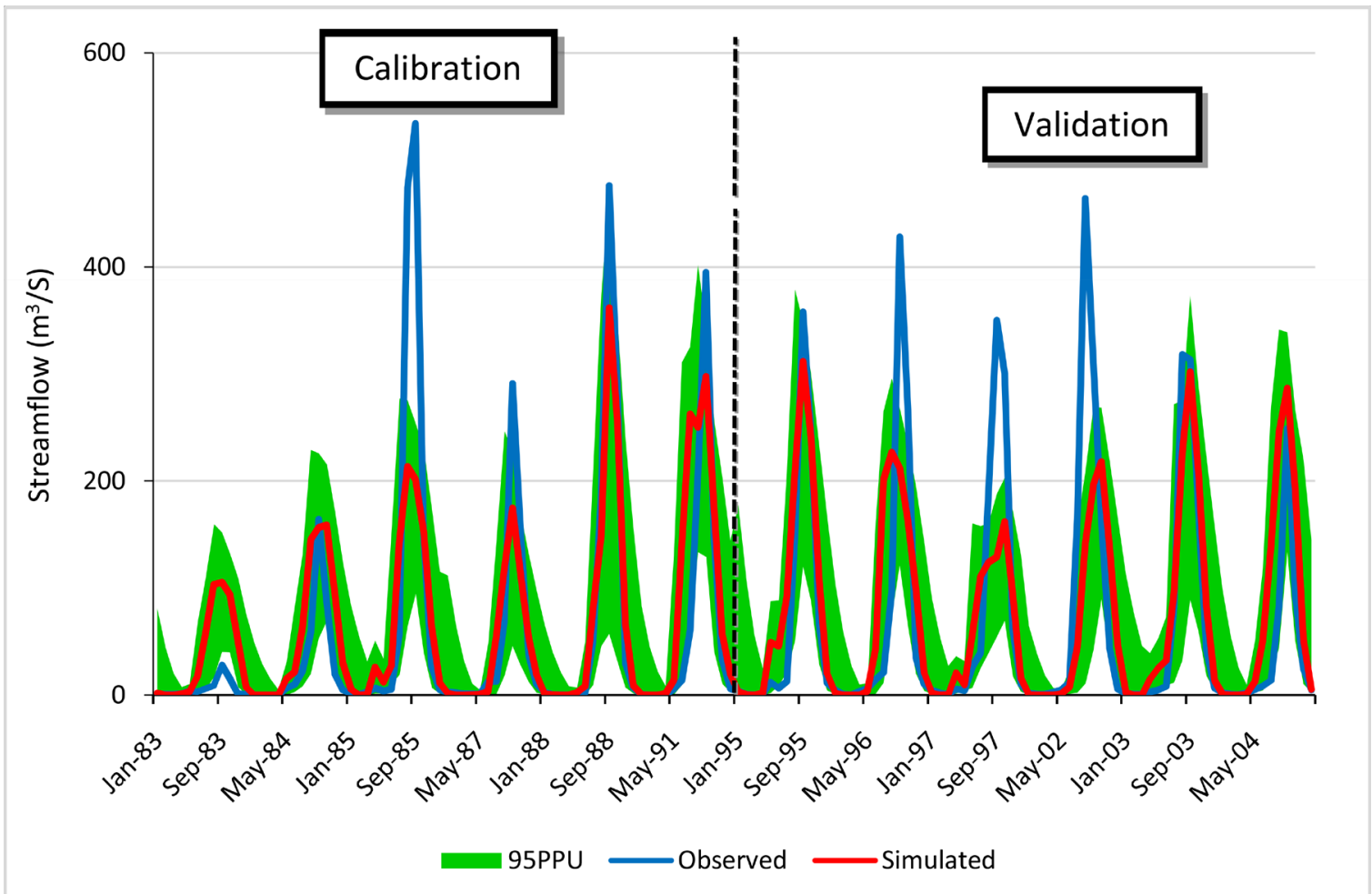

Figure 3. Observed and simulated hydrograph for the Marabadiassa station (left calibration period and right validation period). 
The visual analysis of the hydrographs generally shows good synchronism between observed and simulated stream flows with however, a slight underestimation of peak floods in both periods. Several reasons can explain these trends of underestimation of flows. Indeed, the model was fed by different sources of data according to their availability and quality [50]. According to [51] [52], SWAT model is extremely sensitive to the quality of soil data, land use, as well as the preprocessing procedures adopted for geographically distributed data. Yet, the soil map and soil data used for the modeling were obtained from the FAO regional database. The latter does not accurately represent the basin soil characteristics. In addition to the soil map, the small-scale of landuse map does not define the different crops and land uses clearly enough. Other than the detail of the different types of crops, there are several small hydro-agricultural dams upstream of the basin, which were not taken into account during the implementation. The presence of these reservoirs upstream of the watershed changes the spatial availability of the water resource [20]. Other drawbacks of SWAT that could justify the dephasing of hydrographs are linked to the spatial distribution of climate stations [20] [30] and to unobservable data, notably the empiricism of SWAT model [53].

\subsection{Determination of Water Flows in the Reservoir}

Due to the political crises in Côte d'Ivoire, the data of water withdrawn from Loka reservoir cover the period from 1987 to 1997. Thus, the hydrological simulations carried out over this period (1983 to 1997) allowed to reconstitute the various contributions in the Loka reservoir. The average monthly inflow to the reservoir is $0.78 \mathrm{~m}^{3} / \mathrm{s}$, i.e. a water level of $15.30 \mathrm{~mm}$ per month. Figure 4 shows the evolution of the interannual average water flow in the Loka reservoir, as well as water quantities extracted from the reservoir for drinking water supply.

The visual analysis shows that the Loka reservoir, with a maximum capacity of $3000.104 \mathrm{~m}^{3}$ and an area of $187.5 \mathrm{~km}^{2}$, is experiencing a decrease of water volume

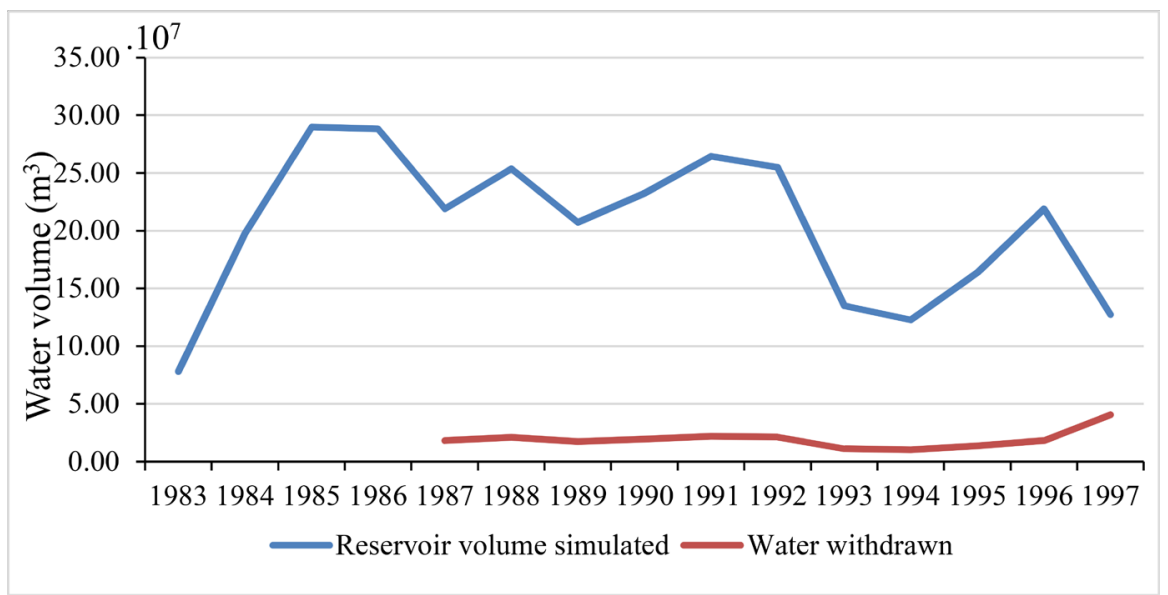

Figure 4. Evolution of the adequacy between the water needs and availability in the Loka reservoir. 
estimated at $384,604.167 \mathrm{~m}^{3} /$ year; i.e. a decrease of $2.26 \%$ per year. Unlike the volume of water in the reservoir, the demand for water undergoes an increase of $2 \%$; that is, a volume of $122,033.3 \mathrm{~m}^{3}$ per year. Hydrological modeling of the Loka basin has shown the impact of climate change as well as anthropization. Indeed, the decrease of Loka reservoir inflows during the period from 1983 to 2018 (drying year) is related to the drop in rainfall.

Yet this decrease in rainfall had been reported in the work of [13] [14] [54] and [55]. In addition, the action of anthropization has been reinforced by the various crises in Côte d'Ivoire, which have made the Bouake city a pole of attraction for indigenous and non-indigenous populations of West African sub-region.

\section{Conclusion}

The work of this study focuses on the assessment of the water availability of the Loka reservoir in Bouaké, face to the uncertainty posed by climate change and anthropization. To better characterize the Loka reservoir, the methodology used was based essentially on agro-hydrological modeling with SWAT. This was based on the performance evaluation criteria of a gauged watershed located near the Loka reservoir. The statistical criteria of the model give satisfactory values of model with an NS of 0.66 , an $\mathrm{R}^{2}$ of 0.68 and a PBIAS of -11.2 for the calibration, and an NS and $\mathrm{R}^{2}$ of 0.59 , and a PBIAS of -3.8 for the validation. From this study, it appears that the average volume of water in the reservoir decreases by $384,604.167 \mathrm{~m}^{3}$ each year. This decrease is partly due to climatic hazards. In addition, the impact of anthropization should not be overlooked, because while the volume of water in the reservoir decreases, the drinking water needs increase. Studies on hydro-climatic variability previously carried out by a number of researchers have shown a drop in rainfall in the study area. It therefore attests the $2 \%$ drop of annual rainfall observed noticed since a few years. To improve the results of this study, it would be desirable to carry out a more detailed study of the soil physico-chemical characteristics. Likewise, to avoid a repetition of the water shortage, a coupling of SWAT model to climate model would be ideal.

\section{Acknowledgements}

The authors would like to thank the Water Distribution Company in Côte d'Ivoire for supporting financially the study. This work was partially supported by the Jean Lorougnon Guédé University through the Laboratory of Environmental Sciences and Technologies. The authors also want to thank Dr. Karim Abbaspour for setting up SWAT model by providing climatic data.

\section{Conflicts of Interest}

The authors declare no conflicts of interest regarding the publication of this paper.

\section{References}

[1] Diabagaté, A., Konan, G.H. and Koffi, A. (2016) Stratégies d'approvisionnement en 
eau potable dans l'agglomération d'Abidjan (Côte d'Ivoire). Geo-Eco-Trop, 4, 345-360.

[2] Kouamé, K.J. (2007) Contribution à la Gestion Intégrée des Ressources en Eaux (GIRE) du District d'Abidjan (Sud de la Côte d'Ivoire): Outils d'aide à la décision pour la prévention et la protection des eaux souterraines contre la pollution. In: Sciences de la Terre et des Ressources Minières, Université de Cocody, Cocody, 225.

[3] Aké, G.E. (2010) Impact of Climate Variability and Anthropogenic Pressure on Waters Resources in the Bonoua Region (South-East of Côte d'Ivoire). University Félix houphouet Boigny, Abidjan, 320. (In French)

[4] Mangoua, M.J. (2013) Évaluation des potentialités et de la vulnérabilité des ressources en eau souterraine des aquifères fissurés du bassin versant de la Baya (Est de la Côte d'Ivoire). In: UFR des Géosciences et Environnement, Université Abobo-Adjamé, Abidjan, 171.

[5] Anoh, K.A. (2014) Apport d'un SIG et du modèle agro-hydrologique SWAT dans la gestion durable des ressources en eau du bassin versant du lac de Taabo (Centre de la Côte d'Ivoire). In: Sciences de la Terre et des Ressources Minières, Félix Houphouët Boigny, Abidjan, 197.

[6] Anoh, K.A., Kouadio, Z.A., Konaté, D., Djè, K.B., Kouassi, K.H., Koua, T.J.-J. and Dibi, B. (2021) Analysis of Climate Disruption Variability in the Sassandra River Basin Limited at Soubré (Western Côte d'Ivoire). International Journal of Innovation and Scientific Research, 54, 90-101.

[7] Koné, J., Yéo, P.A. and Koné, Y.N. (2018) L'eau est une préoccupation majeure en Côte d'Ivoire. 8.

[8] INS, I. N. d. 1. S. (2014) Recensement Général de l'Habitat et de la Population (RGPH), Répertoire des localités: Région du Sud Comoé (Côte d'Ivoire). Institut National de la Statistique, Abidjan, 47.

[9] Djè, B.D. (2018) Évaluation et planification des ressources en eau du bassin versant de la Marahoué (Centre-Ouest de la Côte d'Ivoire). Université Nangui Abrogoua, Abidjan, 83.

[10] Kouamé, K.A. (2013) Application du modèle hydrologique distribué HYDROTEL à la simulation des écoulements des eaux en milieu tropical humide soumis aux pressions anthropiques: Cas du bassin versant du Bandama en Côte d'Ivoire. Université Félix Houphouët-Boigny, Abidjan, 195.

[11] Koua, T.J.J., Jourda, J.P., Kouame, K.J., Anoh, K.A., N’Dri, W.K.C., Lazar, G. and Lane, S. (2014) Effectiveness of Soil and Water Assessment Tool Model to Simulate Water Flow in a Large Agricultural Complex Watershed: Case of Buyo Lake Basin, West of Côte D'Ivoire. Environmental Engineering and Management Journal, 13, 1735-1742. https://doi.org/10.30638/eemj.2014.193

[12] Ouedraogo, M. (2001) Contribution à l'étude de l'impact de la variabilité climatique sur les ressources en eau en Afrique de l'Ouest. Analyse des conséquences d'une sécheresse persistante: Normes hydrologiques et modélisation régionale. Université de Montpellier II (France), Montpellier, 257.

[13] Ardoin, B.S. (2004) Variabilité hydroclimatique et impacts sur les ressources en eau de grands bassins hydrographiques en zone soudano-sahélienne. Université de Montpellier II (France), Montpellier, 330.

[14] Goula, B.T.A., Savané, I., Konan, B., Fadika, V. and Kouadio, G.B. (2005) Etude comparative de l'impact de la variabilité climatique sur les ressources en eau des bassins du N'zo et du N'zi en Côte d'Ivoire. Sciences et Nature, 2, 107-120. https://doi.org/10.4000/vertigo.2038 
[15] Kouassi, A.M. (2007) Caractérisation d'une modification éventuelle de la relation pluie-débit et ses impacts sur les ressources en eau en Afrique de l'Ouest: Cas du bassin versant du N'zi (Bandama) en Côte d'Ivoire. Université de Cocody, Abidjan, 210.

[16] Kouassi, A.M., Kouamé, K.F., Koffi, Y.B., Dje, K.B., Paturel, J.E. and Oulare, S. (2010) Analysis of Climate Variability and of Its Influences on Seasonal Rainfall Regimes in West Africa: Case of the N'zi (Bandama) Watershed in Ivory Coast. $C y$ bergeo: European Journal of Geography, 503, 35-58.

[17] Anoh, K.A., Jourda, J.P., Kouamé, K.J., Koua, T.J.J., Éba, E.A.L. and Lazar, G. (2012) Demarcation of Protection Perimeters for Surface Waters of Taabo (Ivory Coast) Watershed Using GIS and Multicriteria Analysis. Environmental Engineering and Management Journal, 11, 2123-2131. https://doi.org/10.30638/eemj.2012.264

[18] Anoh, K.A., Koua, T.J.J., Eblin, S.G., Kouamé, K.J. and Jourda, J.P. (2017) Modelling Freshwater Availability Using SWAT Model at a Catchment-Scale in Ivory Coast. Journal of Geoscience and Environment Protection, 5, 70-83. https://doi.org/10.4236/gep.2017.513005

[19] Anoh, K.A., Koua, T.J.J., Eblin, S.G., Koudou, A., Kouamé, K.J., Jourda, J.P. and Lazar, G. (2018) Mapping of the Lake Taabo Watershed Surface Waters Intrinsic Vulnerability in Côte d'Ivoire to Diffuse Phosphorus Fluxes. Revue Internationale des Sciences et Technologie, 32, 131-152. (In French)

[20] Anoh, K.A., Koua, T.J.J., Kouamé, K.J., Jourda, J.P. and Laurent, F. (2018) Modelling Waterflow in a Complex Watershed in Humid a Tropical Area Using Swat: A Case Study of Taabo Watershed in Ivory Coast. International Journal of River Basin Management, 16, 157-167. https://doi.org/10.1080/15715124.2017.1387122

[21] Arnold, J.G., Allen, P.M. and Bernhardt, G. (1993) A Comprehensive SurfaceGroundwater Flow Model. Journal of Hydrology, 142, 47-69.

https://doi.org/10.1016/0022-1694(93)90004-S

[22] Payraudeau, S. (2002) Modélisation distribuée des flux d'azote sur des petits bassins versants méditerranéens. ENGREF (AgroParisTech), 449.

[23] RNA 2001, R. N. d. l. A. (2004) Analyse des données. Rapports des statistiques agricoles en Côte d'Ivoire, 38.

[24] Merz, R. and Blöschl, G. (2004) Regionalisation of Catchment Model Parameters. Journal of Hydrology, 287, 95-123. https://doi.org/10.1016/j.jhydrol.2003.09.028

[25] Parajka, J., Merz, R. and Blöschl, G. (2005) A Comparison of Regionalisation Methods for Catchment Model Parameters. Hydrology and Earth System Sciences, 9, 157-171. https://doi.org/10.5194/hess-9-157-2005

[26] Oudin, L. andréassian, V., Perrin, C., Michel, C. and Le Moine, N. (2008) Spatial Proximity, Physical Similarity, Regression and Ungaged Catchments: A Comparison of Regionalization Approaches Based on 913 French Catchments. Water Resources Research, 44, W03413. https://doi.org/10.1029/2007WR006240

[27] Oudin, L., Kay, A. andréassian, V. and Perrin, C. (2010) Are Seemingly Physically Similar Catchments Truly Hydrologically Similar? Water Resources Research, 46, W11558. https://doi.org/10.1029/2009WR008887

[28] Breton-Dufour, M. (2017) Étude de méthodes de régionalisation des paramètres des modèles hydrologiques et application à un bassin versant non-jaugé au Mexique, École de technologie supérieure.

[29] Neitsch, S.L., Arnold, J.G., Kiniry, J.R. and Williams, J.R. (2011) Soil and Water As- 
sessment Tool Theoretical Documentation Version 2009. Texas Water Resources Institute, College Station.

[30] Anoh, K.A., Koua, T.J.J., Yeo, W.E., Eblin, S.G., Kouame, K.J. and Jourda, J.P. (2021) Application of the Agro-Hydrologic SWAT Model on the Taabo River Basin (Côte d'Ivoire) to Evaluate the Effect of Three Vegetative Filter Strip Scenarios on Streamflow and Nutrients. Environmental Engineering \& Management Journal (EEM), 20, 13-23. https://doi.org/10.30638/eemj.2021.002

[31] Abbaspour, C.K. (2013) SWAT-CUP 2012: SWAT Calibration and Uncertainty Programs-A User Manual. 103.

[32] Arnold, J.G., Moriasi, D.N., Gassman, P.W., Abbaspour, K.C., White, M.J., Srinivasan, R., Santhi, C., Harmel, R., Van Griensven, A. and Van Liew, M.W. (2012) SWAT: Model Use, Calibration, and Validation. Transactions of the ASABE, 55, 1491-1508. https://doi.org/10.13031/2013.42256

[33] Van Griensven, A. (2005) Sensitivity, Auto-Calibration, Uncertainty and Model Evaluation in SWAT2005. Unpublished Report, 25.

[34] Koua, T.J.-J., Jourda, J.P., Kouame, K.J. and Anoh, K.A. (2013) Assessment of Sediment and Pollutants in Buyo Lake, Ivory Coast, Using SWAT (Soil and Water Assessment Tool) Model. Journal of Chemistry and Chemical Engineering, 7, 1054-1059.

[35] Koua, T.J.-J., Jourda, J.P., Kouame, K.J., Anoh, K.A., Balin, D. and Lane, S.N. (2014b) Potential Climate Change Impacts on Water Resources in the Buyo Lake Basin (Southwest of Ivory Coast). International Journal of Innovation and Applied Studies, 8, 1094.

[36] Koua, J.-J.T., Anoh, A.K., Soro, D.T., Kouame, J.K. and Jourda, R.J.P. (2019) Evaluation of Agricultural Practices Scenarios for Reducing Erosion in Buyo Lake Catchment (Sassandra; Côte d'Ivoire) by Use of GIS. Journal of Geoscience and Environment Protection, 7, 154-171. https://doi.org/10.4236/gep.2019.77011

[37] Schuol, J., Abbaspour, C.K., Srinivasan, R. and Yang, H. (2008) Estimation of Freshwater Availability in the West African Sub-Continent Using the SWAT Hydrologic Model. Journal of Hydrology, 352, 30-49.

https://doi.org/10.1016/j.jhydrol.2007.12.025

[38] Schuol, J., Abbaspour, K.C., Yang, H., Srinivasan, R. and Zehnder, J.B.A. (2008) Modeling Blue and Green Water Availability in Africa. Water Resources Research, 44, 1-18. https://doi.org/10.1029/2007WR006609

[39] Khalid, K., Ali, M.F., Abd Rahman, N.F., Mispan, M.R., Haron, S.H., Othman, Z. and Bachok, M.F. (2016) Sensitivity Analysis in Watershed Model Using SUFI-2 Algorithm. Procedia Engineering, 162, 441-447. https://doi.org/10.1016/j.proeng.2016.11.086

[40] Nicholson, S.E. (1980) The Nature of Rainfall Fluctuations in Subtropical West Africa. Monthly Weather Review, 108, 473-487. https://doi.org/10.1175/1520-0493(1980)108<0473:TNORFI >2.0.CO;2

[41] Thiébault, M. (2010) Modélisation hydrologique d'un scénario de changement climatique sur le bassin versant du Bani avec SWAT. ENGEES, Strasbourg, 55.

[42] Santhi, C., Arnold, J.G., Williams, J.R., Dugas, W.A., Srinivasan, R. and Hauck, L.M. (2001) Validation of the Swat Model on a Large Rwer Basin with Point and Nonpoint Sources. JAWRA Journal of the American Water Resources Association, 37, 1169-1188. https://doi.org/10.1111/j.1752-1688.2001.tb03630.x

[43] Moriasi, D.N., Arnold, J.G., Van Liew, M.W., Bingner, R.L., Harmel, R.D. and 
Veith, T.L. (2007) Model Evaluation Guidelines for Systematic Quantification of Accuracy in Watershed Simulations. Transactions of the ASABE, 50, 885-900. https://doi.org/10.13031/2013.23153

[44] Rasolomanana, S.D. (2012) Modélisation des petits bassins versants en milieu rural: Problématique des modèles fortement paramétrés. Université Laval Québec (Canada), Québec, 170.

[45] Chaponnière, A. (2005) Hydrological Functioning of a Semi-Arid Mountainous Watershed: Case of the Rehraya Watershed (Moroccan High Atlas). National Agronomic Institute, Paris. (In French)

[46] Getachew, H.E. and Melesse, A.M. (2012) The Impact of Land Use Change on the Hydrology of the Angereb Watershed, Ethiopia. International Journal of Water Sciences, 1, 1-7. https://doi.org/10.5772/56266

[47] Obuobie, E. (2008) Estimation of Groundwater Recharge in the Context of Future Climate Change in the White Volta River Basin, West Africa. Ecology Series, University of Bonn, Bonn, 153.

[48] Schuol, J. and Abbaspour, K.C. (2006) Calibration and Uncertainty Issues of a Hydrological Model (SWAT) Applied to West Africa. Advances in Geosciences, 9, 137-143. https://doi.org/10.5194/adgeo-9-137-2006

[49] Van Liew, M.W., Arnold, J. and Bosch, D. (2005) Problems and Potential of Autocalibrating a Hydrologic Model. Transactions of the ASAE, 48, 1025-1040. https://doi.org/10.13031/2013.18514

[50] Neitsch, S.L., Arnold, J.G., Kiniry, J.R. and Williams, J.R. (2005) Soil and Water Assessment Tool Theoretical Documentation, Version 2005. Grassland, Soil and Water Research Laboratory-Agricultural Research Service. Blackland Research Center, Temple, 476.

[51] Romanowicz, A.A., Vanclooster, M., Rounsevell, M. and La Junesse, I. (2005) Sensitivity of the SWAT Model to the Soil and Land Use Data Parametrisation: A Case Study in the Thyle Catchment, Belgium. Ecological Modelling, 187, 27-39. https://doi.org/10.1016/j.ecolmodel.2005.01.025

[52] Chen, L., Wang, G., Zhong, Y. and Shen, Z. (2016) Evaluating the Impacts of Soil Data on Hydrological and Nonpoint Source Pollution Prediction. Science of the Total Environment, 563-564, 19-28. https://doi.org/10.1016/j.scitotenv.2016.04.107

[53] Laurent, F., Ruelland, D. and Chapdelaine, M. (2007) Simulation de l'effet de changements de pratiques agricoles sur la qualité des eaux avec le modèle SWAT. Revue des sciences de P eau, 20, 395-408. https://doi.org/10.7202/016913ar

[54] Brou, Y.T. (2005) Climat, mutations socio-économiques et paysages en Côte d'Ivoire. Mémoire de synthèse des activités scientifiques présenté en vue de l'obtention de l'Habilitation à Diriger des Recherches, Université des Sciences et Techniques de Lille, France 212.

[55] Kouamé, K.F., Bernier, M., Goné, D., Saley, M., Lefèbre, R., Soro, N. and Koudou, A. (2007) Intégration de données géospatiales dans un modèle hydrologique distribué pour la simulation des écoulements des eaux en milieu tropical humide de Côte d'Ivoire (Afrique de l'Ouest). Revue Télédétection, 7, 217-235. 